\title{
Anti-Neospora caninum IgG in fetal bovine serum
}

\section{Anti-Neospora caninum IgG em soro fetal bovino}

\section{Caroline Zamperete Reginato ${ }^{1}$; Fagner D'ambroso Fernandes ${ }^{2 *}$; Patricia Braünig'; Luis Antônio Sangioni ${ }^{4}$; Fernanda Silveira Flores Vogel ${ }^{4}$}

\author{
Highlights: \\ Transplacental Transmission of Neospora caninum. \\ Neospora caninum protozoan vertical transmission in fetal bovine sérum. \\ Epidemiology of neosporosis in fetal bovine serum.
}

\begin{abstract}
Neospora caninum is an obligate intracellular protozoan, recognized as an important cause of abortion in infection cattle worldwide, and is responsible for major economic losses in beef and dairy herds. There are scarce data on the presence of antibodies in fetal serum samples from beef cattle. The pathogen is straggling mainly by vertical transmission in ruminants. This study aimed to determine the frequency of anti- $N$. caninum antibodies in fetal bovine serum. Overall, 751 fetal serum samples from slaughterhouses in Uruguaiana and Santo Ângelo (Rio Grande do Sul state) were used. Serologic diagnosis was made using indirect immunofluorescence assay (IFA). Slides were prepared by culturing infected Vero cells using tachyzoites of the $N$. caninum $\mathrm{NC}-1$ strain and a serum dilution of 1:25. Of the 751 samples analyzed, $11.7 \%$ (88/751) were positive in the IFA assay. The results indicate an occurrence of neosporosis in the studied region, as well as the possibility of transplacental transmission of the protozoon, characterizing an important mechanism of propagation for the disease.
\end{abstract}

Key words: Serum. Abortion. Transplacental transmission.

\section{Resumo}

O Neospora caninum é um protozoário intracelular obrigatório, reconhecido como uma causa importante de aborto no mundo todo, e é responsável pelas maiores perdas da economia de carne e leite. Há poucos dados da presença de anticorpos em amostras de soro fetal de bovinos de corte. Os patógenos são transmitidos principalmente por transmissão vertical em ruminantes. Este estudo pode ser usado para determinar a frequência de anti- $N$. caninum em soro fetal bovino. Ao todo, foram utilizadas 751 amostras de soro fetal bovino de matadouros de Uruguaiana e Santo Ângelo (RS). Os diagnósticos sorológicos foram realizados utilizando ensaios de imunufluorescência indireta (IFA). As lâminas foram preparadas por cultura de células Vero infectadas utilizando taquizoítos da estirpe $N$. caninum $\mathrm{NC}-1$ e uma diluição de soro de 1:25. Das 751 amostras analisadas, 11,7\% (88/751) foram positivas para o IFA. Os resultados indicam uma ocorrência de neosporose na região estudada, bem como a possibilidade de transmissão transplacentária do protozoário, caracterizando um importante mecanismo de propagação da doença.

Palavras-chave: Soro. Aborto. Transmissão vertical.

1 Discente do Curso de Doutorado do Programa de Pós-Graduação em Medicina Veterinária, Universidade Federal de Santa Maria, UFSM, Santa Maria, RS, Brasil. E-mail: carolreginato@gmail.com

2 Discente do Curso de Graduação em Medicina Veterinária, UFSM, Santa Maria, RS, Brasil. E-mail: fagnermedvet@gmail.com

3 Técnica Administrativa, UFSM, Santa Maria, RS, Brasil. E-mail: pbraunig@gmail.com

4 Profs., UFSM, Santa Maria, RS, Brasil. E-mail: lasangioni@gmail.com; fefevogel@gmail.com

* Author for correspondence 
Neosporosis is caused by Neospora caninum, an obligate intracellular protozoan belonging to the phylum Apicomplexa, and is one of the main causes of bovine abortion worldwide (Dubey \& Lindsay, 1996). The life cycle of $N$. caninum is indirect; the definitive host is canid and intermediate hosts include varied mammalian species, such as ruminants, equines and canids (Mcallister et al., 1998).

The presence of dogs near breeding cattle may be a risk factor for the occurrence of neosporosis (Mcallister et al., 1998), however, infection through ingestion of sporulated oocysts is not considered the main route for transmission of the protozoan (Wouda, Dubey, \& Jekins, 1997). Transplacental infection is important in the epidemiology of bovine neosporosis and is considered the main form of transmission in cattle (Dubey \& Lindsay, 1996). The detection of antibodies in serum samples from calves deprived of colostrum demonstrates vertical infection and transplacental infection efficiency (Wouda et al., 1997). Due to the difficulty in isolating $N$. caninum and the establishment of persistent infection, serological tests have become a useful tool in the detection of specific antibodies (Björkman \& Uglla, 1999).

The main clinical signs associated with neosporosis in cattle are related to reproductive complications and abortion is common, occurring in the second or third stage of gestation (Wouda et al., 1997).

The frequency of antibodies is known to vary widely. This variation can be attributed to sampling, history of reproductive disease, serological test used, dilution of the sample and age of the animals. This study aims to estimate the frequency of antibodies in serum samples of fetuses collected in abattoirs from beef cattle, providing further insight on the mechanisms of vertical transmission of this protozoan in cattle.

A total of 751 samples of fetal bovine serum from abattoirs inspected under the State Inspection Service (CISPOA) in the state of Rio Grande do Sul were analyzed. The samples were collected from bovine fetuses, regardless of the pregnancy stage or reproductive history. After sampling, the blood samples were centrifuged at $3500 \mathrm{rpm}$ for $10 \mathrm{~min}$ to harvest blood serum and subsequently stored at $-20{ }^{\circ} \mathrm{C}$ until use. Serologic diagnosis was performed using indirect immunofluorescence assay (IFA), using VERO cells infected with tachyzoites of the $N$. caninum NC-1 strain. The cut-off point considered indicative of infection was 1:25 (Wouda et al., 1997). A commercial conjugated anti-bovine IgG was used as a secondary antibody (Sigma). Positive and negative control samples for anti-Neospora caninum antibodies were used in all sample slides tested.

Anti-Neospora caninum antibodies were detected in $11.7 \%(88 / 751)$ of the bovine fetal serum samples tested.

Compared with other studies that detected antibodies in bovine fetal serum samples in Brazil, the frequency detected in this study was higher than the $1.4 \%$ found by Marques et al. (2011) and similar to those detected by Guedes, Guimarães, Rocha and Hirsch (2008), Cadore, Vogel, Sangioni, Pena and Gennari (2010), and Amaral et al. (2012), i.e., $12.7 \%, 115 \%$, and $16.7 \%$, respectively. In Argentina, Moore et al. (2002) detected antibodies in $12.1 \%$ of fetal bovine serum samples collected in abattoirs. A similar study in Germany found $12.6 \%$ of fetuses were positive for the antibody (Sondgen et al., 2001). All these works were performed with 1:25 dilution. The results of the present study are important, as few studies have detected antibodies in fetal serum samples from beef cattle herds.

The presence of anti-Neospora caninum. antibodies in fetal serum samples is indicative of transplacental infection. The bovine placenta is cotyledonary and epitheliochorial and does not allow the transfer of maternal immunoglobulins to the fetus. Anti-Neospora caninum. antibodies in fetal bovine serum also indicates that there is no passive immunity to infection. Although the frequency of anti-Neospora caninum. antibodies in fetal bovine 
serum samples was relatively high, false negatives are possible. In fetuses with a gestational age of less than 6 months, the immune system is not mature enough to respond to antigenic stimuli and produce antibodies (Buxton, Mcallister, \& Dubey, 2002).

The frequency of anti-Neospora caninum. antibodies varies widely. In Brazil, the results vary from $6.8 \%$ (Costa et al., 2001) to $97.2 \%$ (Guedes et al., 2008). The results of this study are similar to those of other epidemiological studies conducted in cattle herds in Rio Grande do Sul. Corbellini, Driemeier, Cruz, Gondim and Wald (2002) found $11.2 \%$ of animals were positive for anti-Neospora caninum. antibodies. Our study demonstrates the importance of transplacental infection in fetal samples. Therefore, serological diagnosis and monitoring of animals are necessary to reduce the number of positive within herds and to limit the effect of $N$. caninum on the environment.

\section{Acknowledgments}

The authors thank Coordination of Improvement of Higher Level Personal for funding support.

\section{References}

Amaral, R. L. G., Silva, L. B. G., Pinheiro, J. W., Jr., Souza, O. L., Leal, C. A. S., Porto, W. J. N.,... Mota, R. A. (2012). Neospora caninum em bovinos em matadouros de Pernambuco e Alagoas. Pesquisa Veterinária Brasileira, 32(10), 963-966. doi: 10.1590/S0100-736X2012001000002

Björkman, C., \& Uggla, A. (1999). Serological diagnosis of Neospora caninum infection. International Journal of Parasitology, 29(10), 1497-1507. doi: 10.1016/S0020-7519(99)00115-0

Buxton, D., McAllister, M. M., \& Dubey, J. P. (2002). The comparative pathogenesis of neosporosis. Trends in Parasitology, 18(12), 546-552. doi: 10.1016/S14714922(02)02414-5

Cadore, G. C., Vogel, F. S. F., Sangioni, L. A., Pena, H. F. J., \& Gennari, S. M. (2010). IgM e IgG como marcadores da infecção transplacentária por Neospora caninum em fetos bovinos. Pesquisa
Veterinária Brasileira, 30(7), 551-553. doi: 10.1590/ S0100-736X2010000700007

Corbellini, L. G., Driemeier, D., Cruz, C. F., Gondim, L. F., \& Wald, V. (2002). Neosporosis as a cause of abortion in dairy cattle in Rio Grande do Sul, southern Brazil. Veterinary Parasitology, 103(3), 195-202. doi: 10.1016/s0304-4017(01)00600-08

Costa, G. H. N., Cabral, D. D., Varandas, N. P., Sobral, E. A., Borges, F. A., \& Castagnolli, K. L. (2001). Frequência de anticorpos anti-Neospora caninum e anti-Toxoplasma gondii em soros de bovinos pertencentes aos estados de São Paulo e Minas Gerais. Semina: Ciências Agrárias, 22(1), 61-66. doi: 10.5433/1679-0359.2001v22n1p61

Dubey, J. P., \& Lindsay, D. S. (1996). A review of Neospora caninum and neosporosis. Veterinary Parasitology, 67(1), 1-59. doi: 10.1016/S03044017(96)01035-7

Guedes, M. H. P., Guimarães, A. M., Rocha, C. M. B. M., \& Hirsch, C. (2008). Frequência de anticorpos antiNeospora caninum em vacas e fetos provenientes de municípios do sul de Minas Gerais. Revista Brasileira de Parasitologia Veterináira, 17(4), 189194. doi: 10.1590/S1984-29612008000400004

Marques, F. A. C., Headley, A. S., Figueredo-Pereira, V., Taroda, A., Barros, L. D., Cunha, I. A. L.,... Garcia, J. L. (2011). Neospora caninum: evaluation of vertical transmission in slaughtered beef cows (Bos indicus). Parasitology Research, 108(4), 1015-1019. doi: 10.1007/s00436-010-2146-X

McAllister, M. M., Dubey, J. P., Lindsay, D. S., Jolley, W. R., Wills, R. A., \& McGuire, A. M. (1998). Dogs are definitive hosts of Neospora caninum. International Journal of Parasitology, 28(9), 1473-1478. doi: 10.1016/S0020-7519(98)00138-6

Moore, D. P., Campero, C. M., Odeón, A. C., Posso, M. A., Cano, D., Leunda, M. R.,... Späth, E. (2002). Seroepidemiology of beef and dairy herds and fetal study of Neospora caninum in Argentina. Veterinary Parasitology, 107(4), 303-316. doi: 10.1016 / S03044017 (02) 00129-2

Sondgen, P., Peters, M., Bärwald, A., Wurm, R., Holling, F., Conraths, F. J., \& Schares, G. (2001). Bovine neosporosis: immunoblot improves foetal serology. Veterinary Parasitology, 102(4), 279-290. doi: 10.1016/S0304-4017(01)00543-X

Wouda, W., Dubey, J. P., \& Jenkins, M. C. (1997). Serological diagnosis of bovine fetal neosporosis. Journal of Parasitology, 83(3), 545-547. doi: $10.2307 / 3284431$ 
